\title{
Analisis Peningkatan Keterampilan Problem- Solving Siswa SMP dalam Pembelajaran Matematika dengan IDEAL Problem-Solving berbasis Game-Based Learning
}

\author{
Nadia Karima Maula ${ }^{\# 1}$ \\ Jurusan Teknologi Pendidikan Fakultas Ilmu Pendidikan Universitas Negeri Malang \\ Jalan Semarang No. 5 Malang \\ ${ }^{1}$ nadia.maula.18012160students.um.ac.id
}

\begin{abstract}
This research is a research review of articles with the aim of proving a hypothesis. The articles that the researchers examined are articles in the last ten years, both nationally and internationally. The hypothesis that the researchers want to prove is that there is an increase in the problem solving ability of junior high school students in mathematics using the IDEAL Problem Solving model based on Game Based Learning, especially in Indonesia. IDEAL Problem Solving model has steps, namely Identify the problem (identifying problems), Define goals (defining goals), Explore possible strategies (explore possible strategies), Anticipate outcomes and actions (anticipating outputs and actions), and Look back and learn (reviewing and learning). The IDEAL Problem Solving model is suitable for solving well-structured type problems. The type of game in this study is Role Playing Game. The conclusion of this research is that the application of the IDEAL Problem Solving model based on Game Based Learning with game types of Role Playing Games can increase motivation, interest, and problem solving abilities of junior high school students, especially in mathematics.
\end{abstract}

Keywords —Game Based Learning; IDEAL Problem Solving; Mathematics; Problem Solving Skills.

Abstrak - Penelitian ini merupakan penelitian telaah artikel dengan tujuan membuktikan sebuah hipotesis. Artikelartikel yang peneliti telaah merupakan artikel dalam sepuluh tahun terakhir, baik di lingkup nasional maupun internasional. Hipotesis yang ingin peneliti buktikan yaitu adanya peningkatan kemampuan pemecahan masalah siswa Sekolah Menengah Pertama dalam mata pelajaran matematika menggunakan model IDEAL Problem Solving berbasis Game Based Learning, khususnya di Indonesia. Model IDEAL Problem Solving memiliki langkah-langkah yaitu Identify the problem (mengidentifikasi masalah), Define goal (mendefinisikan tujuan), Explore possible strategies (menelusuri strategi-strategi yang mungkin), Anticipate outcomes and act (mengantisipasi keluaran dan beraksi), dan Look back and learn (meninjau kembali dan belajar). Model IDEAL Problem Solving cocok untuk memecahkan masalah jenis well-structured. Jenis gim pada penelitian ini adalah Role Playing Game. Simpulan dari penelitian ini yaitu penerapan model IDEAL Problem Solving berbasis Game Based Learning dengan gim jenis Role Playing Game dapat meningkatkan motivasi, minat, dan kemampuan pemecahan masalah siswa Sekolah Menengah Pertama terutama dalam mata pelajaran matematika.

Kata Kunci - Kemampuan Pemecahan Masalah; Matematika; Pemecahan Masalah IDEAL; Pembelajaran Berbasis Gim.

\section{PENDAHULUAN}

Pendidikan merupakan hal yang sangat penting bagi manusia, karena pendidikan adalah investasi sumber daya manusia untuk jangka panjang. Pendidikan juga merupakan wadah untuk meningkatkan dan mengembangkan kualitas sumber daya manusia. Perkembangan dunia pendidikan menuntut lembaga pendidikan untuk menyesuaikan perkembangan ilmu pengetahuan dan teknologi dengan pendidikan yang ada di negara kita karena perkembangan ini memberikan pengaruh besar terhadap dunia pendidikan.

Untuk menghadapi tantangan perkembangan teknologi 
yang sangat pesat itu, manusia dituntut agar handal dan mampu berkompetensi secara global, sehingga diperlukan keterampilan yang tinggi, pemikiran yang kritis, sistematis, logis, kreatif dan kemauan kerja yang efektif. Cara berpikir seperti ini dapat dikembangkan melalui pendidikan matematika, karena matematika merupakan dasar dari ilmu pengetahuan yang lain, khususnya bagi perkembangan ilmu pengetahuan dan teknologi.

Matematika merupakan ilmu universal yang mempunyai peran penting dalam berbagai disiplin dan memajukan daya pikir manusia yang diajarkan untuk membekali siswa dengan kemampuan berpikir logis, analitis, sistematis, kritis, dan kreatif serta bekerjasama [1]. Matematika diterapkan sejak TK hingga perguruan tinggi. Tingkat kesulitan materi yang diajarkan berbeda-beda sesuai jenjangnya, hal ini membuktikan bahwa manusia selalu dituntut untuk berkompetensi dalam bidang matematika agar dapat menumbuhkan kemampuan matematika. Salah satu kemampuan pembelajaran matematika adalah problem solving. Pernyataan ini juga didukung oleh tujuan pembelajaran tingkat SMP [2] yang termasuk memecahkan masalah yang meliputi kemampuan memahami masalah, merancang model matematika, menyelesaikan model dan menafsirkan solusi yang diperoleh. Pemecahan masalah harusnya menjadi fokus utama dari kurikulum matematika. Maka ini adalah tujuan utama dari semua pengajaran matematika dan merupakan bagian integral dari semua kegiatan matematika.

Pemecahan masalah bukanlah topik yang berbeda tetapi suatu proses yang harus menembus seluruh program dan memberikan konteks di mana konsep dan keterampilan dapat dipelajari [3]. Pemecahan masalah adalah sintesis aturan dan konsep lain menjadi aturan tingkat tinggi yang dapat diterapkan pada situasi terbatas [4]. Selain itu, pengajaran harus dilakukan dalam konteks, dan siswa harus belajar konten sambil memecahkan masalah yang realistis [5]. Standar pelatihan profesional juga membahas mengenai keterampilan pemecahan masalah. Sekolah kedokteran, teknik, dan bisnis sedang memperbaiki kurikulum mereka untuk fokus pada pemecahan masalah sebagai komponen kunci dari kurikulum profesional [6], [7]. Karena para pendidik menginginkan pembelajaran yang lebih terintegrasi, pemecahan masalah sering berfungsi sebagai untaian kurikulum inti yang berkaitan erat dengan berbagai disiplin ilmu, aturan, konsep, strategi, dan keterampilan. Di samping itu, keterampilan pemecahan masalah, khususnya yang interpersonal juga ditemukan secara signifikan berkaitan dengan efikasi diri sosial [8].

Namun sayangnya, mata pelajaran matematika belum menjadi mata pelajaran yang diminati oleh banyak siswa. Masih banyak yang menganggap matematika sebagai mata pelajaran yang susah, rumit, dan angker karena begitu ditakuti. Dari berbagai bidang studi yang diajarkan di sekolah, matematika merupakan bidang studi yang dianggap paling sulit oleh para siswa, baik yang tidak berkesulitan belajar, maupun yang berkesulitan belajar (Abdurrahman,
2009). Selain itu, saat ini proses belajar mengajar kurang terencana dengan baik. Proses pembelajaran matematika sekarang jarang melibatkan soal-soal pemecahan masalah yang relevan sehingga kemampuan problem solving siswa masih rendah. Kemampuan problem solving (pemecahan masalah) merupakan kecakapan atau potensi yang dimiliki siswa dalam menyelesaikan permasalahan dan mengaplikasikannya dalam kehidupan sehari-hari. Kemampuan pemecahan masalah merupakan salah satu keterampilan yang sangat dibutuhkan dalam pembelajaran matematika ataupun bidang lain. Seharusnya fokus utama dalam pembelajaran adalah belajar menyelesaikan masalah [9]. Branca menyatakan bahwa kemampuan memecahkan masalah adalah tujuan utama dalam pembelajaran matematika, oleh karena itu kemampuan memecahkan masalah hendaknya diberikan, dilatihkan, dan dibiasakan kepada peserta didik sedini mungkin [10]. Selain itu, keberhasilan proses pembelajaran matematika dapat diukur dari keterampilan siswa dalam memahami serta menerapkan konsep dalam memecahkan masalah [11].

Pemecahan masalah adalah keterampilan dasar yang dibutuhkan oleh pebelajar masa kini. Pemecahan masalah termasuk keterampilan berpikir tingkat tinggi seperti visualisasi, asosiasi, abstraksi, pemahaman, manipulasi, penalaran, analisis, sintesis, generalisasi. Masing-masing perlu 'dikelola' dan 'terkoordinasi' [12]. Kemampuan pemecahan masalah dapat dilihat dari berbagai aspek lain, seperti berpikir positif terhadap masalah, berpikir secara sistematis, mengemukakan masalah, mencari dan mengumpulkan fakta, memfokuskan pikiran pada hal-hal penting dan mengemukakan gagasan-gagasan untuk pemecahan masalah [13]. Meski begitu, pemisahan konten dari penerapan telah mempengaruhi sistem pendidikan kita [14]. Pebelajar sering mempelajari fakta dan menghafal prosedur dengan sedikit koneksi langsung dengan konteks dan penerapan pengetahuan.

Rendahnya kemampuan pemecahan masalah siswa dapat diatasi dengan strategi pembelajaran yang lebih efektif. Strategi pembelajaran adalah metode yang diterapkan dalam proses pembelajaran untuk membantu peserta didik memperoleh, mengelola, mengintegrasikan pengetahuan, dan memecahkan masalah secara mandiri [15]. Beberapa indikator kemampuan pemecahan masalah yaitu mampu mengklarifikasi istilah konsep yang belum jelas, mampu merumuskan dan menganalisis masalah, mampu menata gagasan secara sistematis dan menganalisisnya dengan dalam, dan mampu mencari informasi dari sumber lain [16].

Model pembelajaran yang dapat meningkatkan kemampuan problem solving yaitu model IDEAL Problem Solving. Langkah-langkahnya yaitu mengidentifikasi masalah, mendefinisikan tujuan, menggali solusi, melaksanakan strategi, serta mengkaji kembali dan mengevaluasi pengaruhnya. Model ini sangat berkaitan erat dengan model pembelajaran PBL, yang dapat meningkatkan kemampuan pemecahan masalah siswa [17] dan diharapkan dapat mengembangkan keterampilan berpikir kritis. 
Salah satu contoh model penyelesaian masalah adalah IDEAL Problem Solving [18]. IDEAL Problem Solving diperkenalkan sebagai pendekatan yang dapat membantu menyelesaikan masalah [19]. IDEAL, atau Identify the problem, Define goal, Explore possible strategies, Anticipate outcomes and act, dan Look back and learn, dapat digunakan untuk menyelesaikan masalah yang terdefinisi dengan baik (well-structured problem). Strategi IDEAL Problem Solving berusaha mengarahkan siswa untuk memahami masalah, mengajukan pertanyaan, menghubungkan setiap hal yang diketahui dari sebuah data, mengembangkan hipotesis, mencari dan menyaring informasi, merumuskan permasalahan, mencari berbagai alternatif pemecahan yang mungkin, kemudian memilih alternatif yang paling tepat, melakukan langkah pemecahan sesuai alternatif tersebut, kemudian mengoreksi kembali hasil yang telah diperoleh, apakah sudah tepat dan sempurna atau belum.

Masalah sendiri, adalah sesuatu yang harus diselesaikan atau dipecahkan. Secara umum, pengertian masalah adalah kesenjangan antara harapan dengan kenyataan, antara apa yang diinginkan atau yang dituju dengan apa yang terjadi atau faktanya. Suatu masalah biasanya memuat situasi yang mendorong seseorang untuk menyelesaikannya, tanpa mengetahui secara langsung apa yang harus dikerjakan untuk menyelesaikannya. Jika seseorang tersebut saat diberikan suatu masalah langsung mengetahui cara menyelesaikannya, maka masalah tersebut sebenarnya tidak dapat dikatakan sebagai suatu masalah.

Proses belajar dipandang sebagai rangkaian sejumlah subproses yang masing-masing memegang peranan terbatas, dan setiap subproses berlangsung selama jangka waktu tertentu. Pandangan ini bersumber pada teori belajar pemrosesan informasi, yang menggambarkan berpikir sebagai suatu rangkaian peristiwa dalam "otak" yang meliputi urutan langkah pengolahan informasi dari saat diterima hingga dilepaskan lagi. Setiap langkahnya merupakan proses penanganan informasi tersendiri. Teori pemrosesan informasi menganalisis cara anak memanipulasi informasi, memonitornya, dan menciptakan strategi untuk menanganinya. Kemampuan memperhatikan informasi yang relevan meningkat dengan mantap selama tahun-tahun sekolah dasar dan menengah. Pemrosesan informasi yang datang memerlukan perhatian selektif terhadap kejadian, obyek, simbol, dan stimulus tertentu lainnya agar informasi itu dapat dipelajari. Beberapa penelitian lain menyatakan bahwa "perhatian" siswa bisa dideskripsikan sebagai "manajer garis depan" yang penting dalam menentukan informasi yang akan diberikan untuk pemrosesan lebih lanjut, juga berperan sebagai "penjaga gerbang" dengan menentukan sejauh mana persepsi dalam pembelajaran tergantung dengan tuntutan tugas [20]. Perhatian yang selektif dapat mempengaruhi pembelajaran dan memaksimalkan keterampilan pemecahan masalah. Perhatian yang selektif dibentuk oleh reward pembelajaran yang memerlukan pengawasan aktif dari keterampilan pemecahan masalah.
Kemampuan pemecahan masalah harus ditumbuhkembangkan dalam pembelajaran matematika. Setiap pengajar matematika hendaknya memberi perhatian terhadap kemampuan pemecahan masalah setiap melakukan kegiatan pembelajaran. Kemampuan pemecahan masalah yang harus ditumbuhkan adalah sebagai berikut. (1) Kemampuan mengerti konsep dan istilah matematika; (2) kemampuan mencatat kesamaan, perbedaan, dan analogi; (3) kemampuan untuk mengidentifikasi elemen terpenting dan memilih prosedur yang benar; (4) kemampuan untuk mengetahui hal yang tidak berkaitan; (5) kemampuan untuk menaksir dan menganalisa; (6) kemampuan untuk memvisualisasi dan mengimplementasi kuantitas atau ruang; (7) kemampuan untuk menggeneralisasi berdasarkan beberapa contoh; (8) kemampuan untuk mengganti metode yang telah diketahui, dan (9) mempunyai kepercayaan diri yang cukup dan merasa senang terhadap materinya [21], [22].

Untuk mengembangkan kemampuan di atas, guru mata pelajaran matematika seharusnya memperhatikan hal-hal berikut, yaitu (1) mengajarkan siswa berbagai strategi yang dapat digunakan untuk berbagai masalah; (2) memberikan waktu yang cukup kepada siswa untuk mencoba menyelesaikan masalah yang ada; (3) mengajak siswa untuk menyelesaikan masalah dengan cara lain; (4) setelah masalah diselesaikan, guru mengajak siswa untuk melihat kembali, melihat kemungkinan lain, mengatakan dengan bahasa mereka sendiri, kemudian mengajak untuk mencari penyelesaian dengan cara yang lebih baik atau strategi yang lebih efektif; (5) mengajarkan kepada siswa jika berhadapan dengan masalah yang sulit, tidak langsung menghindar, dan (6) menumbuhkan fleksibilitas di dalam pemecahan masalah.

Guru juga perlu menanamkan sikap dan kebiasaan seperti berikut kepada siswa, (1) tidak mudah menyerah; (2) mengemukakan ide atau gagasan dengan logis; (3) terbuka untuk setiap strategi pemecahan masalah; (4) siswa didorong untuk bereksperimen dengan suatu strategi terhadap masalahmasalah lainnya; (5) siswa dibelajarkan dengan kerjasama dalam kelompok, dan (6) siswa dididik untuk menghargai setiap ide atau gagasan siswa lainnya.

Di era digital ini, teknologi informasi dan komunikasi berkembang pesat, salah satu perwujudannya adalah digitalisasi permainan dengan menggunakan teknologi komputer. Perkembangan ilmu pengetahuan dan teknologi ini semakin mendorong upaya-upaya pembaharuan dalam pemanfaatan teknologi untuk diterapkan pada proses belajar [23]. Berbagai macam pemanfaatan komputer dalam bidang edukasi dengan tujuan agar proses pembelajaran berlangsung secara lebih optimal, interaktif, efektif, dan efisien sehingga mutu pendidikan dalam negeri dapat meningkat. Penggunaan komputer sebagai media pembelajaran memungkinkan terlaksananya proses pembelajaran secara individual disebabkan menumbuhkan kemandirian dalam proses belajar sehingga siswa akan mengalami proses yang jauh lebih bermakna dibandngkan dengan pembelajaran secara tradisional atau konvensional [24], [25]. Digitalisasi dapat meningkatkan dan mempromosikan minat belajar siswa 
[26]-[28] dan karenanya membantu mereka terlibat dalam situasi belajar [29]-[33]. Maka, permainan digital dapat membantu perkembangan belajar siswa.

Proses belajar yang baik menekankan prinsip pengalaman, pemahaman, serta pembiasaan. Peneliti akan menekankan prinsip-prinsip tersebut dalam menerapkan alternatif strategi pembelajaran berbasis digital Game Based Learning, yaitu menggunakan aplikasi permainan atau gim yang telah dirancang khusus untuk membantu dalam proses pembelajaran. Bermain game adalah salah satu aktivitas yang digemari oleh anak-anak maupun orang dewasa. Secara tidak langsung, game dapat mengasah memori otak. Selain itu, aktivitas ini juga dianggap sebagai penghilang rasa stres setelah padat beraktivitas yang lain. Dampak positif lain dari bermain game adalah melatih konsentrasi dan logika karena terdapat tugas dan aturan yang harus diselesaikan dan dipatuhi dalam game tersebut. Salah satu hubungan antara pembelajaran dan permainan atau gim adalah bahwa dalam keduanya terdapat umpan balik formatif, bagian yang cukup penting dari usaha belajar apapun [34]. Transfer atau perpindahan pengetahuan dari game komputer dapat dilakukan dengan merancang game yang berisi konten pembelajaran [35]. Pada umumnya pola yang digunakan dalam media ini adalah proses pembelajaran melalui pola learning by doing [36].

Selama dekade terakhir, video game telah menjadi salah satu industri terkait waktu luang yang paling menguntungkan, dengan jutaan pemain di seluruh dunia [37]. Dampak tinggi dari industri video game telah menghasilkan peningkatan minat dalam pemanfaatan praktis teknik AI dan CI dalam video game komersial. Saat ini, terdapat sejumlah besar konferensi internasional yang mengusulkan berbagai kompetisi, atau tantangan, yang tujuan utamanya didasarkan pada pemanfaatan teknik AI dan CI untuk memecahkan masalah seperti: tingkat penyelesaian otomatis, definisi karakter non-pemain otonom (yaitu otonom bots), pembuatan level secara otomatis, dll [38].

Gim penelitian ini yaitu Role Playing Game karena menggunakan metode problem solving di dalam permainannya. Jenis gim ini pemainnya memainkan atau memiliki penekanan pada sebuah tokoh, karakter, atau peran perwakilan pemain di dalam permainan, dan cenderung terdapat alur cerita yang harus dilewati, dijalankan, atau diselesaikan [39], [40]. Role Playing Game adalah gim yang karakter utamanya dapat berubah dan berkembang ke arah yang diinginkan pemain, seperti menjadi semakin hebat, kuat, dan lain-lain dalam berbagai parameter yang biasanya ditentukan dengan kenaikan status kekuatan karakter, senjata yang semakin sakti, ataupun jumlah teman [39].

\section{Metode PENELITIAN}

Metode yang digunakan dalam penelitian ini adalah metode kualitatif, dengan pendekatan studi literasi. Penelitian ini dilakukan dengan melihat kecenderungan atau masalah yang ada dalam proses pembelajaran, terutama pada model pembelajaran yang digunakan, yang menunjukkan bahwa siswa merasa bosan dan kesulitan belajar matematika dengan model pembelajaran konvensional tersebut. Dengan demikian penelitian ini akan memberikan pemahaman atau solusi bagi guru untuk mengubah model pembelajaran yang sebelumnya menggunakan metode konvensional menjadi pembelajaran berbasis gim berdasarkan IDEAL ProblemSolving, yang jika diterapkan membawa dampak cukup positif terhadap kemampuan kognitif dan afektif siswa di Indonesia [41].

\section{HASIL DAN PEMBAHASAN}

Pada proses pembelajaran matematika saat ini, guru cenderung mendominasi dan hanya mengajar apa yang ada di buku pelajaran, dan siswa pasif, hanya mempelajari apa yang akan diujikan dan merasa bosan. Kondisi ini kurang mendukung pengembangan kreativitas dan kemampuan pemecahan masalah mereka untuk masa mendatang. Padahal pemecahan masalah merupakan komponen penting dari kurikulum dan inti dari aktivitas matematika, sehingga kemampuan pemecahan masalah di kalangan siswa perlu mendapat perhatian dalam pembelajaran. Untuk melatih kreativitas siswa diperlukan kegiatan yang memberikan kesempatan pada siswa untuk menggunakan daya pikir, mengembangkan ide, menemukan solusi suatu masalah agar mereka dapat mengembangkan kemampuan pemecahan masalah dengan baik. Kunci keterlibatan siswa dalam penyelesaian masalah adalah rancangan pembelajaran yang fokus terhadap masalah-masalah yang relevan, maka diperlukan pengajaran khusus untuk mendukung pembelajaran penyelesaian masalah [42], [43].

Kesulitan yang ditemui di SMA Islam Sultan Agung 3 Semarang adalah karena tidak diadakannya pengamatan keterampilan pemecahan masalah, sehingga kurang mengetahui rendahnya kemampuan pemecahan masalah siswa. Masalah adalah pusat pengajaran matematika, pembelajaran, dan dasar untuk aktivitas intelektual di kelas. Masalah matematika membentuk siswa untuk belajar matematika. Materi yang dirasa sulit oleh siswa adalah dimensi tiga, yang dalam pemahamannya diperlukan proses pada diri siswa untuk mencoba dan melakukan analisis terhadap suatu obyek [44]. Chaim menyatakan bahwa siswa sulit mengkomunikasikan informasi visual [45]. Kemudian kesulitan yang ditemui di SMP Negeri 7 Pematangsiantar adalah bahwa siswa mengalami kesulitan mengerjakan soalsoal pemecahan masalah diakibatkan karena dalam pemecahan masalah biasanya melibatkan beberapa kombinasi konsep dan keterampilan siswa dalam situasi berbeda. Sedangkan siswa di sekolah tersebut hanya menggunakan rumus-rumus yang ada tanpa memahami konsepnya terlebih dahulu, sehingga jika diberikan soal yang berbeda dari soal yang sebelumnya, siswa sulit mengerjakan soal tersebut [46].

Penyelesaian masalah adalah proses beberapa langkah di mana pemecah masalah harus menemukan hubungan antara 
pengalaman masa lalu (skema) dan masalah yang dihadapi kemudian bertindak berdasarkan solusi [47]. Mayer juga mengemukakan tiga karakteristik penyelesaian masalah, yaitu (1) pemecahan masalah termasuk pencapaian kognitif tetapi disimpulkan dari perilaku; (2) pemecahan masalah menghasilkan perilaku yang mengarah ke solusi, dan (3) pemecahan masalah adalah proses yang melibatkan manipulasi atau operasi pada pengetahuan sebelumnya [48].

Pemecahan masalah menurut Krulik dan Rudnick [49] didefinisikan sebagai cara seorang individu menggunakan pengetahuan sebelumnya untuk memperoleh pengetahuan, keterampilan, dan pemahaman untuk memenuhi tuntutan situasi yang asing. Pemecahan masalah juga mencakup komponen sikap dan kognitif. Untuk memecahkan masalah, peserta didik harus ingin melakukannya, dan mereka harus percaya mereka bisa. Aspek motivasi dan sikap seperti usaha, kepercayaan diri, kegelisahan, kegigihan dan pengetahuan tentang diri penting untuk proses pemecahan masalah [50]. Penilaian terhadap keterampilan pemecahan masalah mencakup penilaian kreativitas dalam melihat bermacammacam kemungkinan penyelesaian, dan kemampuan memahami masalah, merencanakan pemecahan masalah serta melaksanakannya, menafsirkan hasilnya [51], [52].

Pembelajaran IDEAL Problem Solving berlandaskan pada psikologi kognitif sebagai pendukung teoritisnya. Fokus pengajaran banyak pada apa yang siswa pikirkan (kognisi mereka) pada saat mereka melakukan proses belajar. Menurut Dewey, sekolah harusnya mencerminkan masyarakat yang lebih besar dan kelas merupakan laboratorium untuk pemecahan masalah kehidupan yang nyata. Pendapat Dewey ini memberikan dasar filosofis dari IDEAL Problem Solving. John Dewey mengemukakan pentingnya berpikir reflektif, dan proses yang seharusnya membantu siswa menerapkan keterampilan berpikir produktif dan keterampilan proses. Jerome Bruner menekankan pentingnya pembelajaran discovery dan bagaimana guru seharusnya membantu siswa menjadi "pembangun" pengetahuan mereka sendiri (Muchayat, 2011).

Penjelasan terhadap 5 tahap IDEAL Problem Solving adalah sebagai berikut. (1) Identify the problem (Mengidentifikasi masalah), guru membantu siswa dalam memahami aspek-aspek permasalahan seperti membantu mengembangkan atau menganalisis perasalahan, mengajukan pertanyaan, mengkaji hubungan antar data, memetakan masalah, dan mengembangkan hipotesishipotesis; (2) Define the problem (Mendefinisikan masalah dan menetapkan tujuan), guru membantu dan membimbing siswa melihat data atau variabel yang sudah diketahui dan yang belum diketahui, mencari berbagai informasi, menyaring berbagai informasi yang ada dan akhirnya merumuskan permasalahan; (3) Explore solutions (Mencari solusi), guru membantu dan membimbing siswa mencari berbagai alternatif pemecahan masalah, melakukan brainstorming, melihat alternatif pemecahan masalah dari berbagai sudut pandang lalu akhirnya memilih satu alternatif pemecahan masalah yang tepat; (4) Act the strategy
(Melaksanakan strategi), siswa dibimbing secara tahap demi tahap dalam melakukan pemecahan masalah sesuai dengan alternatif yang telah dipilih, dan (5) Look back and evaluate the effect (Mengkaji kembali dan mengevaluasi pengaruh), guru membimbing siswa melihat atau mengoreksi kembali cara-cara pemecahan masalah yang telah dilakukan, apakah sudah benar, sempurna, atau lengkap. Siswa juga dibimbing melihat pengaruh strategi yang digunakan dalam pemecahan masalah.

Pembelajaran dalam penyelesaian masalah harus difokuskan pada dua tipe pengetahuan berbeda, yaitu pengetahuan deklaratif dan prosedural [4]. Pengetahuan deklaratif termasuk fakta, konsep, dan prinsip serta merupakan pengetahuan khusus konten atau faktual dalam ranah disiplin atau keterampilan. Tabel di bawah ini menjelaskan tentang tiga tipe pengetahuan deklaratif.

TABEL I

TIPE PENGETAHUAN DEKLARATIF DAN CONTOHNYA

\begin{tabular}{|l|l|}
\hline $\begin{array}{l}\text { Tipe Pengetahuan } \\
\text { Deklaratif }\end{array}$ & Contoh \\
\hline $\begin{array}{l}\text { Fakta ("tahu apa"-asosiasi } \\
\text { sederhana) }\end{array}$ & $\begin{array}{l}\text { Mobil ini adalah Chevrolet } \\
\text { Camaro 1998 }\end{array}$ \\
\hline $\begin{array}{l}\text { Konsep ("ketahui itu"-kemampuan } \\
\text { untuk dengidentifikasi dan } \\
\text { mengelompokkan contoh) }\end{array}$ & $\begin{array}{l}\text { Jenis mobil termasuk coupe dan } \\
\text { sedan }\end{array}$ \\
\hline $\begin{array}{l}\text { Prinsip ("tahu mengapa"- } \\
\text { kemampuan untuk memprediksi dan } \\
\text { menjelaskan perilaku suatu sistem) }\end{array}$ & $\begin{array}{l}\text { Jika Anda memutar setir } \\
\text { searah jarum jam, maka mobil } \\
\text { akan berbelok ke kanan (karena } \\
\text { setir memindahkan gigi rak \& } \\
\text { pinion yang terhubung lengan } \\
\text { yang memutar roda) }\end{array}$ \\
& \\
\hline
\end{tabular}

Pemecah masalah membentuk model mental berdasarkan situasi yang sedang dimanipulasi. Memecahkan masalah biasanya membutuhkan pemecah masalah untuk merestrukturisasi secara dinamis dan "menjalankan" model mental mereka dari sistem untuk memprediksi efek tindakan yang diusulkan pada sistem atau untuk menjelaskan perilaku sistem yang diamati. Dengan demikian, mengembangkan model mental dengan jenis struktur yang tepat untuk memecahkan kelompok masalah tertentu adalah kunci keberhasilan pemecahan masalah. Jenis model mental yang dikembangkan tergantung pada masalah apa yang diharapkan dapat diselesaikan dengannya.

Pengetahuan deklaratif yang dimiliki para pemecah masalah ahli dengan yang masih pemula dapat dibedakan dalam tiga cara, yaitu (1) pemecah masalah ahli memiliki pemahaman yang lebih dalam dan representasi dari domain (konteks). Pemecah masalah ahli dapat memanfaatkan pengetahuan yang luas dari pengalaman masa lalu yang memecahkan masalah analog dalam domain yang sama, dan dapat beralih di antara berbagai metode dan strategi [53]. Sedangkan pemecah masalah pemula tidak tahu sebanyak itu tentang konteksnya. Pemula membuat lebih banyak kesalahan daripada para ahli, dan kesalahan mereka sebagian besar terkait dengan kesalahpahaman daripada kecerobohan atau tebakan acak; (2) pemecah masalah ahli mensintesis pengetahuan deklaratif mereka yang kaya, menghasilkan 
model mental pribadi yang berubah secara dinamis dari sistem atau ruang masalah untuk memecahkan kelompok masalah tertentu. Sedangkan pemecah masalah pemula sering mengandalkan model mental yang naif, kurang lengkap, tidak terstruktur, dan bahkan salah. Kesalahan pemodelan mental ini sering menjadi sumber kesalahan pemecahan masalah pemula, dan (3) pemecah masalah ahli memiliki sikap positif dan keyakinan bahwa masalah dapat diselesaikan melalui analisis persisten [53]. Pemula sering tidak memiliki karakteristik ini.

Keterampilan memecahkan masalah peserta didik tidak dapat naik melebihi pengetahuan deklaratifnya, sehingga tidak benar bahwa menekankan penyelesaian masalah dalam kurikulum berhasil dengan tidak mengajarkan pengetahuan deklaratif, tetapi pengetahuan deklaratif harus diajarkan dengan cara yang menimbulkan pelajar mengaturnya untuk pemecahan masalah. Masalah pun dapat dibedakan jenisnya, tipe-tipe masalah yang kita temui beragam dari struktur yang dimiliki. Masalah sering direpresentasikan dari yang terstruktur dengan baik, kemudian cukup terstruktur, hingga tidak terstruktur [54]. Posisi masalah pada rangkaian ini menentukan cara ia diajarkan dan dipelajari. Model IDEAL Problem Solving adalah model yang dapat memecahkan masalah jenis terstruktur dengan baik (well-structured). Masalah well-structured adalah masalah yang selalu menggunakan solusi langkah demi langkah yang sama. Karakteristik masalah jenis ini yaitu (1) Strategi solusi biasanya dapat diduga, (2) hanya ada satu jawaban benar, dan (3) semua informasi awal biasanya merupakan bagian dari pernyataan masalah. Beberapa contoh dari permasalahan ini adalah menyeimbangkan buku cek, mengikuti resep, dan memecahkan teka-teki silang. Implikasinya dalam pengajaran dan pengujian mengikuti keadaan sebagai berikut.

(1) Bergantung pada pengetahuan deklaratif, tetapi dengan kedalaman pengetahuan yang paling sedikit; (2) keterampilan untuk ini terbatas pada jenis masalah yang serupa. Tidak bisa digunakan untuk memecahkan jenis masalah yang lain; (3) pebelajar hanya menghafal prosedur; tugas sering menjadi otomatis dengan latihan, dan (4) mudah dimasukkan ke dalam alat bantu kerja dan sistem pendukung kinerja.

Untuk menyelesaikan masalah, seseorang harus menguasai hal-hal yang telah dipelajari sebelumnya kemudian menggunakannya di dalam situasi baru. Karena itu masalah yang disajikan kepada peserta didik harus sesuai dengan kemampuan dan kesiapan peserta didik. Aktivitas pembelajaran tidak hanya difokuskan pada upaya mendapatkan pengetahuan sebanyak-banyaknya, melainkan juga bagaimana menggunakan segenap pengetahuan yang didapat untuk menghadapi situasi baru atau memecahkan masalah-masalah khusus yang berkaitan dengan bidang studi yang dipelajari. Hakikat pemecahan masalah adalah melakukan operasi prosedural urutan tindakan, tahap demi tahap secara sistematis, sebagai seorang pemula memecahkan suatu masalah.
Beberapa penelitian sebelum penelitian ini yang relevan dengan judul yang saya angkat membuahkan hasil-hasil seperti yang akan peneliti jelaskan berikut ini. Peneliti terdahulu telah menyatakan bahwa pengetahuan tentang konteks adalah fitur keterampilan yang paling penting dalam pemecahan masalah. Pemecahan masalah telah menjadi sarana untuk menggabungkan kembali konten dengan penerapannya dalam lingkungan belajar untuk keterampilan dasar serta penerapan mereka dalam berbagai konteks. Pembelajaran dikatakan efektif jika ada peningkatan keterampilan pemecahan masalah. Untuk meningkatkan keterampilan pemecahan masalah siswa, diterapkan model IDEAL Problem Solving. Langkah-langkah model ini dapat menggali kreativitas siswa untuk mengidentifikasi masalah, mendefinisikan tujuan dan menggali penyelesaian yang mungkin dilakukan [51].

Penelitian Triyono yang lalu pun menyebutkan bahwa proses belajar matematika peserta didik pada tingkat SMP masih belum optimal, dalam arti masih banyak siswa yang belum mampu memahami masalah dan pemecahannya [55]. Dalam pengajaran matematika, banyak guru yang mengeluh kurang optimalnya kemampuan siswa dalam pemecahan masalah. Hal ini terlihat dari banyaknya kesalahan siswa dalam mengerjakan soal-soal, dan rendahnya potensi belajar siswa (nilai) baik dalam ulangan harian mau pun dalam ujian semester.

Hasil penelitian lain menunjukkan bahwa ketertarikan dan prestasi sebagian besar siswa meningkat drastis apabila mereka diberi kesempatan dan difasilitasi untuk membuat hubungan antara informasi atau pengetahuan yang telah dimiliki sebelumnya. Keterlibatan siswa dalam kegiatan pembelajaran juga sangat meningkat saat mereka difasilitasi untuk mengetahui tujuan pembelajaran [56]. Kirkley menyimpulkan beberapa hasil penelitian yang telah dilakukan terhadap IDEAL Problem Solving sebagai berikut: (1) IDEAL Problem Solving lebih unggul dalam meningkatkan kemampuan pemecahan masalah siswa SMA dibandingkan dengan strategi pemecahan masalah yang lain, (2) Penerapan IDEAL Problem Solving terbukti secara signifikan dapat meningkatkan hasil belajar siswa dalam pemecahan masalah bidang IPA [57].

Sebuah penelitian pada tahun 2011 membuahkan hasil yang menunjukkan bahwa kreativitas siswa berpengaruh terhadap kemampuan pemecahan masalah sebesar $68,6 \%$. Penerapan perangkat pembelajaran model IDEAL Problem Solving dapat menghantarkan siswa melampaui KKM sebesar 80,56\% [51]. Kemudian hasil penelitian Durrotul Falahah dengan menggunakan pendekatan IDEAL Problem Solving pada materi fungsi komposisi di kelas XI Madrasah Muhammadiyah 1 Malang menunjukkan bahwa pembelajaran yang dilakukan oleh guru dan siswa berjalan dengan baik. Pembelajaran ini juga dinilai efektif karena respon siswa mencapai persentase $74,46 \%$ yang dikategorikan kuat. Temuan dari penelitian di tahun 2014 lalu menunjukkan bahwa motivasi peserta didik menentukan keterlibatan mereka selama bermain gim, yang pada 
gilirannya menentukan pengembangan kompetensi pemecahan masalah yang kompleks. Temuan dari penelitian tersebut juga menunjukkan bahwa motivasi peserta didik, keterlibatan, dan kinerja pemecahan masalah sangat dipengaruhi oleh sifat dan desain tugas permainan [58]. Model pembelajaran IDEAL Problem Solving sangat berkaitan erat dengan model pembelajaran Problem-Based Learning, yang terbukti dapat meningkatkan kemampuan pemecahan masalah. Pernyataan ini didukung oleh sebuah penelitian yang menunjukkan hasil bahwa implementasi Problem-Based Learning meningkatkan kemampuan mengidentifikasi kesulitan-kesulitan belajar, menyarankan ide penelitian dan sumber daya, dan menyarankan alasan awal untuk masalah dan solusi yang memungkinkan [59].

Beberapa penelitian menggunakan gim berjenis RPG sebagai sarana edukasi. Dalam sebuah penelitian di tahun 2017, terdapat pernyataan sangat mendukung bahwa media pembelajaran berbasis role play game education sangat dianjurkan dalam pembelajaran matematika agar dapat menarik motivasi dan minat peserta didik [60]. Gim jenis Role Playing Game ini diterapkan untuk membangun sebuah platform pembelajaran yang adaptif, dengan tujuan utama untuk meningkatkan pengalaman belajar pemain dengan skenario permainan yang interaktif [61].

Terdapat prinsip-prinsip yang mendukung pemecahan masalah matematis, beberapa diantaranya yaitu the prolonged engagement principle (agar peserta didik dapat meningkatkan kemampuan pemecahan masalah matematika, mereka harus terlibat dalam mengerjakan pemecahanpemecahan masalah secara rutin, selama durasi tertentu), the task variety principle (peserta didik akan meningkat kemampuannya sebagai pemecah masalah hanya jika mereka diberikan kesempatan untuk memecahkan beragam jenis permasalahan), the complexity principle (terdapat interaksi dinamis antara konsep matematis dan proses yang digunakan untuk memecahkan masalah terkait konsep-konsep tersebut), dan the assessment principle (agar peserta didik percaya perilaku baik yang dimotori oleh program pemecahan masalah penting, sebaiknya guru menggunakan teknik asesmen pemberian hadiah terhadap perilaku seperti itu) [62].

Terkait dengan teknologi pembelajaran dan ilmu berbasis komputer, terdapat sebuah penelitian yang menampakkan bahwa terdapat peningkatan drastis dalam pencapaian dan keterampilan pemecahan masalah dari siswa-siswa dalam kelompok eksperimental yang menerima ilmu berbasis komputer serta teknologi pembelajaran [63]. Penelitian terdahulu lain di tahun 2017 membuahkan hasil yaitu bahwa media pembelajaran berbasis game edukasi sangat valid dan praktis [64]. Gim edukasi yang peneliti teliti dalam penelitian ini adalah jenis gim Role Playing Game. Dalam memainkan Role Playing Game paling tidak dapat dilihat dari dua hal penting yaitu berorientasi eksplorasi atau berorientasi penugasan. Lalu seorang pemain gim akan berinteraksi dengan sistem permainan, interaksi ini disebut dengan Game Playing. Game Playing dianggap sebagai proses penyelesaian masalah (quest atau goal) dengan pemain berperilaku sebagai problem solver, sehingga pemain dihadapkan pada interaksi untuk menyelesaikan tujuan (goal) seperti mengalahkan boss atau menyelesaikan tantangan (quest) [65], [66]

Berikut ini peneliti lampirkan tabel kategorisasi beberapa artikel ilmiah yang peneliti telaah dalam penelitian ini [17], [24], [26], [67], [68].

TABEL III

KATEGORISASI 5 ARTIKEL ILMIAH PENELITIAN

\begin{tabular}{|c|c|c|c|c|c|c|}
\hline $\begin{array}{l}\mathrm{N} \\
\mathrm{o} .\end{array}$ & $\begin{array}{l}\text { Katego } \\
\text { ri }\end{array}$ & $\begin{array}{l}\text { Eko } \\
\text { Andy } \\
\text { Purnomo }\end{array}$ & $\begin{array}{l}\text { Gd. } \\
\text { Gunan } \\
\text { tara }\end{array}$ & $\begin{array}{l}\text { Galang } \\
\text { Prihadi } \\
\text { Mahardh } \\
\text { ika }\end{array}$ & $\begin{array}{l}\text { Chun- } \\
\text { Ming } \\
\text { Hung }\end{array}$ & Alfikri \\
\hline 1. & $\begin{array}{l}\text { Mata } \\
\text { pelajar } \\
\text { an }\end{array}$ & $\begin{array}{l}\text { Matemati } \\
\text { ka }\end{array}$ & $\begin{array}{l}\text { Matem } \\
\text { atika }\end{array}$ & $\begin{array}{l}\text { Pendidik } \\
\text { an } \\
\text { Agama } \\
\text { Islam }\end{array}$ & $\begin{array}{l}\text { Scienc } \\
e\end{array}$ & $\begin{array}{l}\text { Soal- } \\
\text { soal } \\
\text { dalam } \\
\text { website } \\
\text { BEBRA } \\
\text { S }\end{array}$ \\
\hline 2. & $\begin{array}{l}\text { Kelas } \\
\text { subyek } \\
\text { peneliti } \\
\text { an }\end{array}$ & $\begin{array}{l}\text { Mahasis } \\
\text { wa }\end{array}$ & $\begin{array}{l}\text { Kelas } \\
5 \mathrm{SD}\end{array}$ & $\begin{array}{l}\text { Pendidik } \\
\text { an Anak } \\
\text { Usia } \\
\text { Dini }\end{array}$ & $\begin{array}{l}\text { Kelas } \\
5 \text { SD }\end{array}$ & $\begin{array}{ll}\text { Kelas } & 8 \\
\text { SMP } & \end{array}$ \\
\hline 3. & $\begin{array}{l}\text { Model } \\
\text { pembel } \\
\text { ajaran }\end{array}$ & $\begin{array}{l}\text { IDEAL } \\
\text { Problem } \\
\text { Solving }\end{array}$ & $\begin{array}{l}\text { Proble } \\
m \\
\text { Based } \\
\text { Learni } \\
n g\end{array}$ & $\begin{array}{l}\text { Digital } \\
\text { Game } \\
\text { Based } \\
\text { Learning }\end{array}$ & $\begin{array}{l}\text { Projec } \\
t \\
\text { Based } \\
\text { Learni } \\
n g\end{array}$ & $\begin{array}{l}\text { Comput } \\
\text { ational } \\
\text { Thinking }\end{array}$ \\
\hline 4. & $\begin{array}{l}\text { Jenis } \\
\text { gim } \\
\text { pembel } \\
\text { ajaran }\end{array}$ & $\begin{array}{l}\text { Tidak } \\
\text { ada }\end{array}$ & $\begin{array}{l}\text { Tidak } \\
\text { ada }\end{array}$ & $\begin{array}{l}\text { Digital } \\
\text { Story } \\
\text { Telling }\end{array}$ & $\begin{array}{l}\text { Digital } \\
\text { Story } \\
\text { Telling }\end{array}$ & $\begin{array}{l}\text { Role } \\
\text { Playing } \\
\text { Game }\end{array}$ \\
\hline 5. & $\begin{array}{l}\text { Efektiv } \\
\text { itas } \\
\text { dalam } \\
\text { pening } \\
\text { katan } \\
\text { hasil } \\
\text { belajar }\end{array}$ & $\begin{array}{l}\text { Tidak } \\
\text { diuji }\end{array}$ & $\begin{array}{l}\text { Tidak } \\
\text { diuji }\end{array}$ & $\begin{array}{l}\text { Tidak } \\
\text { diuji }\end{array}$ & $\begin{array}{l}\text { Selisih } \\
\text { hasil } \\
\text { belajar } \\
\text { kelom } \\
\text { pok } \\
\text { eksper } \\
\text { imen } \\
\text { denga } \\
\text { n } \\
\text { kelom } \\
\text { pok } \\
\text { kontro } \\
1 \\
\text { adalah } \\
2,56\end{array}$ & $\begin{array}{l}\text { Tidak } \\
\text { diuji }\end{array}$ \\
\hline 6. & $\begin{array}{l}\text { Efektiv } \\
\text { itas } \\
\text { dalam } \\
\text { pening } \\
\text { katan } \\
\text { kemam } \\
\text { puan } \\
\text { pemeca } \\
\text { han } \\
\text { masala } \\
\text { h }\end{array}$ & $\begin{array}{l}\text { Rata-rata } \\
\text { kemamp } \\
\text { uan } \\
\text { pemecah } \\
\text { an } \\
\text { masalah } \\
\text { meningk } \\
\text { at } \\
\text { sebanyak } \\
11 \%\end{array}$ & $\begin{array}{l}\text { Rata- } \\
\text { rata } \\
\text { kema } \\
\text { mpuan } \\
\text { pemec } \\
\text { ahan } \\
\text { masala } \\
\text { h } \\
\text { menin } \\
\text { gkat } \\
\text { sebany } \\
\text { ak } \\
16,42 \\
\%\end{array}$ & $\begin{array}{l}\text { Tidak } \\
\text { diuji }\end{array}$ & $\begin{array}{l}\text { Selisih } \\
\text { kema } \\
\text { mpuan } \\
\text { pemec } \\
\text { ahan } \\
\text { masala } \\
\text { h } \\
\text { kelom } \\
\text { pok } \\
\text { eksper } \\
\text { imen } \\
\text { denga } \\
\text { n } \\
\text { kelom } \\
\text { pok } \\
\text { kontro } \\
\text { l } \\
\text { adalah } \\
0,39\end{array}$ & $\begin{array}{l}\text { Menurut } \\
\text { hasil } \\
\text { kuesione } \\
\mathrm{r} \text { yang } \\
\text { dibagika } \\
\mathrm{n} \text {, rata- } \\
\text { rata } \\
\text { tingkat } \\
\text { penana } \\
\text { man } \\
\text { kemamp } \\
\text { uan } \\
\text { pemecah } \\
\text { an } \\
\text { masalah } \\
\text { adalah } \\
4,8 \text { dari } \\
5\end{array}$ \\
\hline
\end{tabular}




\begin{tabular}{|c|c|c|c|c|c|c|}
\hline 7. & $\begin{array}{l}\text { Efektiv } \\
\text { itas } \\
\text { dalam } \\
\text { pening } \\
\text { katan } \\
\text { motiva } \\
\text { si } \\
\text { belajar } \\
\text { siswa }\end{array}$ & $\begin{array}{l}\text { Tidak } \\
\text { diuji }\end{array}$ & $\begin{array}{l}\text { Tidak } \\
\text { diuji }\end{array}$ & $\begin{array}{l}\text { Tidak } \\
\text { diuji }\end{array}$ & $\begin{array}{l}\text { Selisih } \\
\text { motiva } \\
\text { si } \\
\text { belajar } \\
\text { kelom } \\
\text { pok } \\
\text { eksper } \\
\text { imen } \\
\text { denga } \\
\text { n } \\
\text { kelom } \\
\text { pok } \\
\text { kontro } \\
1 \\
\text { adalah } \\
0,41 \\
\end{array}$ & $\begin{array}{l}\text { Menurut } \\
\text { hasil } \\
\text { kuesione } \\
\mathrm{r} \text { yang } \\
\text { dibagika } \\
\mathrm{n} \text {, rata- } \\
\text { rata } \\
\text { tingkat } \\
\text { motivasi } \\
\text { berpikir } \\
\text { komputa } \\
\text { si siswa } \\
\text { adalah } \\
4,3 \text { dari } \\
5\end{array}$ \\
\hline 8. & $\begin{array}{l}\text { Lokasi } \\
\text { peneliti } \\
\text { an }\end{array}$ & $\begin{array}{l}\text { Jurusan } \\
\text { Pendidik } \\
\text { an } \\
\text { Matemati } \\
\text { ka } \\
\text { Universit } \\
\text { as } \\
\text { Muham } \\
\text { madiyah } \\
\text { Semaran } \\
\text { g }\end{array}$ & $\begin{array}{l}\text { SD } \\
\text { Negeri } \\
2 \\
\text { Sepan } \\
\text { g }\end{array}$ & $\begin{array}{l}\text { Tidak } \\
\text { diinform } \\
\text { asikan, } \\
\text { pengemb } \\
\text { angan } \\
\text { dilakuka } \\
\text { n di } \\
\text { Jurusan } \\
\text { Teknik } \\
\text { Informat } \\
\text { ika } \\
\text { Universi } \\
\text { tas Islam } \\
\text { Indonesi } \\
\text { a } \\
\end{array}$ & $\begin{array}{l}\text { Sebua } \\
\mathrm{h} \text { SD } \\
\text { di } \\
\text { Taiwa } \\
\text { n } \\
\text { Selata } \\
\text { n }\end{array}$ & $\begin{array}{l}\text { Sebuah } \\
\text { SMP di } \\
\text { Yogyak } \\
\text { arta }\end{array}$ \\
\hline 9. & $\begin{array}{l}\text { Waktu } \\
\text { peneliti } \\
\text { an }\end{array}$ & $\begin{array}{l}\text { Tidak } \\
\text { diinform } \\
\text { asikan }\end{array}$ & $\begin{array}{l}\text { Tahun } \\
\text { pelajar } \\
\text { an } \\
2012 / 2 \\
013\end{array}$ & $\begin{array}{l}\text { Tidak } \\
\text { diinform } \\
\text { asikan }\end{array}$ & $\begin{array}{l}\text { Tahun } \\
2011\end{array}$ & $\begin{array}{l}\text { Tidak } \\
\text { diinform } \\
\text { asikan }\end{array}$ \\
\hline
\end{tabular}

\section{KESIMPULAN}

Rendahnya kemampuan pemecahan masalah siswa dapat diatasi dengan strategi pembelajaran yang lebih efektif sehingga pembelajaran dikatakan efektif jika ada peningkatan keterampilan pemecahan masalah atau problem solving skills. Model pembelajaran yang terbukti dapat meningkatkan kemampuan problem solving siswa adalah model IDEAL Problem Solving. Pembelajaran menggunakan model IDEAL Problem Solving menjadikan pembelajaran lebih bermakna, siswa dapat memilih dan mengembangkan ide dan pemikirannya dengan kreativitasnya. Pembelajaran matematika model IDEAL Problem Solving dengan teori pemrosesan informasi untuk pembentukan keterampilan pemecahan masalah akan lebih baik digunakan pada subyek penelitian kelompok tertentu karena dapat meningkatkan keterampilan pemecahan masalah. Berdasarkan analisa terhadap penelitian-penelitian terdahulu, Game Based Learning berdampak signifikan terhadap proses belajar mengajar karena dapat meningkatkan motivasi dan performa siswa dengan cara meningkatkan ketertarikannya terhadap pembelajaran yang dimodelkan [69], [70]. Dalam memainkan sebuah gim berisi teka-teki dan rintangan, seorang individu cenderung menjadi penasaran dan terus mencari solusi. Hal ini membuktikan bahwa penggunaan gim dalam pembelajaran dapat menumbuhkan motivasi para siswa [71]. Beberapa penelitian juga berhasil membuktikan bahwa jenis gim yang digunakan pada penelitian ini, yaitu Role Playing Game, dapat meningkatkan hasil belajar siswa. Terdapat suatu metode tertentu yang telah dibuktikan dapat meningkatkan keterampilan pemecahan masalah, yaitu dari contoh yang dikerjakan [72]. Metode ini dapat diterapkan ke dalam gim edukasi Role Playing Game untuk penelitian ini. Hal lain yang perlu diperhatikan dalam Digital Game Based Learning adalah bahwa ketika merancang Digital Game Based Learning, perancang harus meningkatkan motivasi dan beban kognitif untuk meningkatkan efektivitas pembelajaran. Selain itu, komponen perhatian harus dikompromikan. Namun, relevansi, kepuasan, dan kepercayaan diri tidak bertentangan [73]. Beberapa saran dari penelitian terdahulu yaitu guru sebaiknya memberikan perhatian yang berbeda, sesuai tingkat pemrosesan informasi subyeknya [44], uji coba game edukasi sebaiknya dilakukan di beberapa sekolah untuk mengetahui kualitas dari game edukasi yang dikembangkan, baik pada aspek kepraktisan maupun keefektifan yang mungkin saja berbeda-beda tergantung subyek penelitiannya [74]. Sedangkan untuk proses pembelajarannya, saran bagi guru yaitu dalam proses belajar mengajar guru sebaiknya memberikan perhatian pada karakteristik peserta didik, dan harus menggunakan metode pembelajaran yang sesuai dengan keadaan materi, waktu, dan lainnya dari peserta didik. Saran bagi peserta didik adalah agar peserta didik selalu bersikap aktif, selalu memperhatikan materi yang disampaikan guru secara sungguh-sungguh dan berusaha meningkatkan hasil belajarnya semaksimal mungkin [75].

\section{UCAPAN TERIMA KASIH}

Dengan selesainya penelitian ini, peneliti mengucapkan terima kasih kepada seluruh civitas akademi di Fakultas Ilmu Pendidikan, Universitas Negeri Malang khususnya Jurusan Teknologi Pendidikan yang telah memberikan motivasi, dan bantuan dalam pelaksanaan penelitian ini, sehingga terlaksana dengan baik, lancar, dan sukses.

\section{DAFTAR PUSTAKA}

[1] D. P. Nasional, "Permendiknas No. 22 Tahun 2006 tentang standar isi," Jakarta: Depdiknas, 2006.

[2] B. S. N. Pendidikan, "Kompetensi dan Kompetensi Dasar Matematika SMP," Jakarta BNSP Dep. Pendidik. Nas. Republik Indones., 2006.

[3] N. C. of T. of M. C. on S. for S. Mathematics, Curriculum and evaluation standards for school mathematics. Natl Council of Teachers of, 1989.

[4] R. M. Gagné and R. M. Gagné, Conditions of learning and theory of instruction. Holt, Rinehart and Winston, 1985.

[5] S. C. on A. N. Skills, "What work requires of schools: A SCANS report for America 2000," Washington, DC US Dep. Labor, 1991.

[6] H. S. Barrows and R. M. Tamblyn, Problem-based learning: An approach to medical education. Springer Publishing Company, 1980.

[7] D. R. Woods et al., "Developing problem solving skills: The McMaster problem solving program," J. Eng. Educ., vol. 86, no. 2, pp. 75-91, 1997. 

Interpersonal Problem Solving Skills on Social Self-Efficacy.," Educ. Sci. Theory Pract., vol. 13, no. 2, pp. 739-745, 2013.

[9] D. H. Jonassen, Learning to solve problems: A handbook for designing problem-solving learning environments. Routledge, 2010 .

[10] M. Asikin, "Pengaruh model pembelajaran matematika creative problem solving (CPS) berbantuan CD interaktif terhadap kemampuan pemecahan masalah pada siswa SMA kelas X," Lembaran Ilmu Kependidikan, vol. 37, no. 1, 2008.

[11] F. Rizqiyah, S. Risfaldi, M. Usman, and S. A. Pramuditya, "Kemampuan Pemahaman Matematis Berbantuan Game Edukasi RPG," in Prosiding Seminar Nasional Pendidikan Matematika (SNPM), 2019, vol. 1, no. 1, pp. 322-330.

[12] J. Garofalo and F. K. Lester Jr, "Metacognition, cognitive monitoring, and mathematical performance," J. Res. Math. Educ., pp. 163-176, 1985.

[13] F. H. Rosadi, "Perancangan Media Game Asfire Adventure Tentang Kemampuan Problem Solving pada Mahasiswa Universitas Teknologi Yogyakarta." Universitas Teknologi Yogyakarta, 2019.

[14] J. Hiebert et al., "Problem solving as a basis for reform in curriculum and instruction: The case of mathematics," Educ. Res., vol. 25 , no. 4, pp. 12-21, 1996.

[15] D. Lockhart and R. R. Schmeck, "Learning Styles and Classroom Evaluation Methods: Different Strokes for Different Folks.," Coll. Stud. J., vol. 17, no. 1, pp. 94-100, 1983.

[16] T. Amir, "Inovasi Pendidikan Melalui Pembelajaran Berbasis Masalah: Bagaimana Penddikan Memberdayakan Pemelajararan Di Era Pengetahuan,” Jakarta Kencana Prenad Media Gr., 2009.

[17] G. Gunantara, I. M. Suarjana, and P. N. Riastini, "Penerapan model pembelajaran problem based learning untuk meningkatkan kemampuan pemecahan masalah matematika siswa kelas V," Mimb. PGSD Undiksha, vol. 2, no. 1, 2014.

[18] J. D. Bransford, A. F. Haynes, B. S. Stein, and X. Lin, "The IDEAL Workplace: Strategies for Improving Learning, Problem Solving, and Creativity.," 1998.

[19] B. S. Stein, The IDEAL problem solver: A guide for improving thinking, learning, and creativity. WH Freeman, 1993.

[20] A. Byers and J. T. Serences, "Exploring the relationship between perceptual learning and top-down attentional control," Vision Res., vol. 74, pp. 30-39, 2012.

[21] J. W. Dodson, "Characteristics of successful insightful problem solvers (Doctoral dissertation, University of Georgia, 1970)," Diss. Abstr. Int., vol. 31, pp. 13-71, 1971.

[22] J. L. Hollander, The Arthritis Handbook: A Problem-solving Approach to Arthritis Management. Merck Sharp \& Dohme, 1974.

[23] A. Asriyatun and M. A. Nugroho, "Pengembangan Game Edukatif Berbasis RPG Maker XP Sebagai Media Pembelajaran Akuntansi," J. Pendidik. Akunt. Indones., vol. 12, no. 1, 2014.

[24] M. P. Rusman and R. Cepi, "Belajar dan Pembelajaran Berbasis Komputer," Bandung Alf., 2012.

[25] K. W. Sari, S. Saputro, and B. Hastuti, "Pengembangan game edukasi kimia berbasis role playing game (RPG) pada materi struktur atom sebagai media pembelajaran mandiri untuk siswa kelas X SMA di kabupaten Purworejo," J. Pendidik. Kim., vol. 3, no. 2, pp. 96-104, 2014.

[26] C.-M. Hung, G.-J. Hwang, and I. Huang, "A project-based digital storytelling approach for improving students' learning motivation, problem-solving competence and learning achievement," J. Educ. Technol. Soc., vol. 15, no. 4, pp. 368-379, 2012.

[27] G.-J. Hwang and H.-F. Chang, "A formative assessment-based mobile learning approach to improving the learning attitudes and achievements of students," Comput. Educ., vol. 56, no. 4, pp. 1023-1031, 2011.

[28] J.-L. Shih, C.-W. Chuang, and G.-J. Hwang, "An inquiry-based mobile learning approach to enhancing social science learning effectiveness," J. Educ. Technol. Soc., vol. 13, no. 4, pp. 50-62, 2010

[29] C. Haigh and P. Hardy, "Tell me a story — a conceptual exploration of storytelling in healthcare education," Nurse Educ. Today, vol 31, no. 4, pp. 408-411, 2011.

[30] P. R. Lowenthal, "Digital storytelling: An emerging institutional technology," Story Circ. Digit. Storytell. around world, pp. 252 259, 2009.

[31] P. R. Lowenthal and J. C. Dunlap, "From pixel on a screen to real person in your students' lives: Establishing social presence using digital storytelling," Internet High. Educ., vol. 13, no. 1-2, pp. 7072, 2010.

[32] T. Reitmaier, N. J. Bidwell, and G. Marsden, "Situating digital storytelling within African communities," Int. J. Hum. Comput. Stud., vol. 69, no. 10, pp. 658-668, 2011.

[33] G. Stacey and P. Hardy, "Challenging the shock of reality through digital storytelling," Nurse Educ. Pract., vol. 11, no. 2, pp. 159 $164,2011$.

[34] V. J. Shute, L. Rieber, and R. Van Eck, "Games... and... learning," Trends issues Instr. Des. Technol., vol. 3, pp. 1-31, 2011.

[35] S. Sukirman, "Peningkatan Atmosfer Belajar Siswa Generasi Digital Native Melalui Pembelajaran Berbasis Game,” 2017.

[36] F. Kurniawati, "The Effectiveness of Collaborative Learning For Teaching Descriptive Writing at High School." Universitas Muhammadiyah Purwokerto, 2012.

[37] H. Fuster, U. Oberst, M. Griffiths, X. Carbonell, A. Chamarro, and A. Talarn, "Psychological motivation in online role-playing games: A study of Spanish World of Warcraft players," An. Psicol., vol. 28, no. 1, pp. 274-280, 2012.

[38] A. Gonzalez-Pardo, F. Palero, and D. Camacho, "An empirical study on collective intelligence algorithms for video games problem-solving," Comput. Informatics, 2015.

[39] A. F. Abror, "Mathematics adventure games berbasis role playing game (RPG) sebagai media pembelajaran mata pelajaran matematika kelas VI SD negeri Jetis 1," eprints. uny. ac. id/[diakses 23-1-2013], 2012.

[40] A. D. Wulandari, "Game Edukatif Sejarah Komputer Menggunakan Role Playing Game (RPG) Maker XP Sebagai Media Pembelajaran Di SMP Negeri 2 Kalibawang," Univ. Negeri Yogyakarta, Yogyakarta, 2012.

[41] B. Z. Faqiroh, "Problem Based Learning Model for Junior High School in Indonesia (2010-2019)," Indones. J. Curric. Educ. Technol. Stud., vol. 8, no. 1, 2020.

[42] J. Henton, R. Marotz-Baden, and D. Kieren, "Problem solving in the classroom," Fam. Coord., pp. 61-66, 1979.

[43] D. H. Jonassen, "Instructional design models for well-structured and III-structured problem-solving learning outcomes," Educ. Technol. Res. Dev., vol. 45, no. 1, pp. 65-94, 1997.

[44] A. Nayazik, S. Sukestiyarno, and N. Hindarto, "Peningkatan Karakter dan Pemecahan Masalah Melalui Pembelajaran Ideal Problem Solving-Pemrosesan Informasi," Unnes J. Math. Educ. Res., vol. 2, no. 2, 2013.

[45] J. Johnson, "Teaching and learning mathematics," Off. Supt. Public Instr. Olympia, WA, 2000.

[46] J. K. Pasaribu, "Penerapan Pembelajaran Ideal Problem Solving Untuk Meningkatkan Kemampuan Pemecahan Masalah Matematika Siswa Di Kelas VIII SMP N 7 Pematangsiantar TA 2012/2013." UNIMED, 2013.

[47] R. E. Mayer, P. S. Thinking, and W. H. Cognition, "Freeman and Company," New York, 1983.

[48] C. Funkhouser and J. Richard Dennis, "The effects of problemsolving software on problem-solving ability," J. Res. Comput. Educ., vol. 24, no. 3, pp. 338-347, 1992.

[49] J. Carson, "A problem with problem solving: Teaching thinking without teaching knowledge," Math. Educ., vol. 17, no. 2, 2007.

[50] D. Jonassen and M. Tessmer, "An outcomes-based taxonomy for the design, evaluation, and research of instructional systems," Train. Res. J., vol. 2, no. 1996, p. 97, 1996

[51] I. N. Dhany, "Pengembangan Perangkat Pembelajaran Model IDEAL Problem Solving Materi Dimensi Tiga Kelas X.” Tesis. Semarang: PPs Unnes, 2011.

[52] S. C. U. Munandar, Kreativitas dan keberbakatan: Strategi mewujudkan potensi kreatif dan bakat. Gramedia Pustaka Utama, 
1999.

[53] D. Jonassen, "Instructional Design Model for Practice and Situated Problem-Solving Learning Outcomes," Educ. Technol. Res. Dev. J., 1997.

[54] A. Newell and H. A. Simon, Human problem solving, vol. 104, no. 9. Prentice-Hall Englewood Cliffs, NJ, 1972.

[55] H. HANIFAH, "Peningkatan Kemampuan Problem Solving Melalui Penerapan Pendekatan Problem Posing pada Pembelajaran Matematika Pokok Bahasan Persegi Panjang (PTK Pembelajaran Matematika Kelas VII SMP N 2 Widodaren Ngawi)., Universitas Muhammadiyah Surakarta, 2008.

[56] S. Sugiyono, M. Murdanu, and N. M. Murdiyani, "Pengembangan Perangkat Pembelajaran Matematika pada Topik Geometri Menggunakan Paradigma Baru dalam Pembelajaran Matematika," J. Pendidik. Mat. dan Sains, vol. 2, no. 2, pp. 117-125, 2014.

[57] M. Wena, "Strategi Pembelajaran Inovatif Kontemporer, Jakarta: PT," Bumi Aksara, 2011.

[58] D. Eseryel, V. Law, D. Ifenthaler, X. Ge, and R. Miller, "An investigation of the interrelationships between motivation, engagement, and complex problem solving in game-based learning.," Educ. Technol. Soc., vol. 17, no. 1, pp. 42-53, 2014.

[59] M. M. Ferreira and A. R. Trudel, "The impact of problem-based learning (PBL) on student attitudes toward science, problemsolving skills, and sense of community in the classroom," J. Classr. Interact., pp. 23-30, 2012.

[60] A. Fadli, S. Suharno, and A. A. Musadad, "Deskripsi Analisis Kebutuhan Media Pembelajaran Berbasis Role Play Game Education untuk Pembelajaran Matematika," in Prosiding Seminar Nasional Teknologi Pendidikan, 2017.

[61] D. P. Hermawan, "Efektivitas Penggunaan game edukasi berjenis puzzle, RPG dan Puzzle RPG sebagai sarana belajar matematika." Institut Teknologi Sepuluh Nopember, 2017.

[62] F. K. Lester Jr, "Thoughts about research on mathematical problem-solving instruction," Math. Enthus., vol. 10, no. 1, pp. 245-278, 2013.

[63] O. Serin, "The Effects of the Computer-Based Instruction on the Achievement and Problem Solving Skills of the Science and Technology Students.," Turkish Online J. Educ. Technol., vol. 10, no. 1, pp. 183-201, 2011.

[64] A. P. Rusadi, M. S. Noto, and S. A. Pramuditya, "Desain Media Pembelajaran Berbasis Game Edukasi pada Materi Segi Empat untuk Siswa SMP Kelas VII,” Repos. FKIP Unswagati, 2017.

[65] D. Choi and J. Kim, "Why people continue to play online games: In search of critical design factors to increase customer loyalty to online contents," CyberPsychology Behav., vol. 7, no. 1, pp. 1124, 2004.

[66] D. Kristanto, "Pengaruh Kustomisasi Avatar Game dalam Meningkatkan Pengalaman Pemain dan Loyalitas Bermain: Eksperimen dalam Video Game berbasis Role Playing Game (RPG) The Impact of Game Avatar Customization in Improving User Experience and Gamer Loyalty: Experiment in."

[67] E. A. Purnomo and V. D. Mawarsari, "Peningkatan kemampuan pemecahan masalah melalui model pembelajaran ideal problem solving berbasis project based learning," J. Karya Pendidik. Mat., vol. 1 , no. $1,2014$.

[68] G. P. Mahardhika, "Digital game based learning dengan model ADDIE untuk pembelajaran doa sehari-hari," Teknoin, vol. 22, no. 2,2015

[69] S. Y. S. Hussain, W. H. Tan, and M. Z. Idris, "Digital game-based learning for remedial mathematics students: A new teaching and learning approach In Malaysia," Int. J. Multimed. Ubiquitous Eng., vol. 9, no. 11, pp. 325-338, 2014.

[70] D. La Guardia, M. Gentile, V. Dal Grande, S. Ottaviano, and M. Allegra, "A Game based Learning Model for Entrepreneurship Education," Procedia - Soc. Behav. Sci., vol. 141, pp. 195-199, Aug. 2014, doi: 10.1016/J.SBSPRO.2014.05.034.

[71] M. R. Alfikri, "Penerapan Kemampuan Problem solving Yang Baik Sejak Dini pada Siswa SMP Menggunakan Pendekatan Computational Thinking (CT) Berbasis RPG (Role Playing Game)." Universitas Islam Indonesia, 2019.
T. Van Gog and L. Kester, "A test of the testing effect: acquiring problem-solving skills from worked examples," Cogn. Sci., vol. 36, no. 8, pp. 1532-1541, 2012.

[73] J.-C. Woo, "Digital game-based learning supports student motivation, cognitive success, and performance outcomes," $J$. Educ. Technol. Soc., vol. 17, no. 3, pp. 291-307, 2014

[74] A. Rizal and K. Hernawati, "Pengembangan Game Edukasi Matematika Dengan Pendekatan Guided Discovery Untuk Siswa SMP Kelas VIII," J. Pendidik. Mat., vol. 6, no. 3, pp. 1-8, 2017.

[75] R. Q. Ihza, "Efektifitas metode role playing berbantu media game peti soal harta karun terhadap kemampuan pemecahan masalah soal cerita peserta didik matapelajaran matematika kelas V di MI Miftahul Akhlaqiyah tahun pelajaran 2016/2017." UIN Walisongo, 2017. 